\begin{tabular}{|c|c|c|}
\hline it & $\begin{array}{l}\text { International Journal of Agriculture and Wildlife } \\
\qquad \text { Science } \\
\text { http://dergipark.org.tr/ijaws }\end{array}$ & U. \\
\hline
\end{tabular}

Research Article

\title{
Effects of Thidiazuran and Zeatin on Plant Regeneration in Helichrysum pallasii
}

\author{
Emine Yurteri* (D), Merve Aksu (D) Haydar Küplemez (D), \\ Aysel Özcan (D), Fatih Seyis
}

Field Crops Department, Faculty of Agriculture, Recep Tayyip Erdogan University, Rize, Turkey

Received: 01.06.2021 Accepted: 06.09.2021

\section{Keywords:}

Immortal flower,

micropropagation, tissue culture, thidiazuran, zeatin

\section{*Corresponding author} emine.yurteri@erdogan.edu.tr

\begin{abstract}
The genus of Helichrysum comprises many species which have therapeutical effects and used in folk medicine. H. pallasii is one of these species, used in the region for traditional medicine and ornamental purposes. Therefore, optimizing alternative micropropagation protocols of tissue culture conditions and secondary metabolite production for these species needs attention. The effect of Thidiazuran (TDZ) combined with Zeatin (ZEA) on shoot regeneration in $\mathrm{H}$. pallasi was investigated during this study. The leaf, stem and root parts taken from the seedling germinated under in vitro conditions were used as explants. As a result, the root explants were more efficient compared to other explants in inducing plant regeneration using $1 \mathrm{mg} \mathrm{L}^{-1}$ Thidiazuran (TDZ) +0.1 $\mathrm{mg} \mathrm{L}^{-1}$ Zeatin (ZEA) (88.9\%) and $1 \mathrm{mg} \mathrm{L}^{-1} \mathrm{TDZ}$ treatment (85.7\%). The lowest plant regeneration percentage (16.7\%) was found in control medium using leaf explants.
\end{abstract}

\section{Thiadiazuron ve Zeatin'in Helichrysum pallasii'de Bitki Rejenerasyonuna Etkisi}

\footnotetext{
Anahtar kelimeler: Ölmez çiçek, mikro çoğaltım, doku kültürü, thidiazuran, zeatin
Özet. Helichrysum cinsi, tedavi edici etkileri olan ve halk hekimliğinde kullanılan birçok türü içermektedir. H. pallasii yörede geleneksel tıp ve süs amaçlı kullanılan bu türlerden bir tanesidir. Bu nedenle, bu türler için doku kültüründe alternatif mikroçoğaltım protokollerinin ve sekonder metabolit üretiminin optimize edilmesi gerektirmektedir. Bu çalışmada Zeatin (ZEA) ile kombine edilmiş Thidiazuran (TDZ)' nın $H$. pallasi'de sürgün rejenerasyonu üzerine etkileri incelenmiştir. In vitro koşullarda çimlendirilen bitkiciklerden alınan yaprak, gövde ve kök kısımları eksplant olarak kullanılmıştır. Sonuç olarak, en yüksek bitki rejenerasyonu kök eksplantlarına uygulanan $1 \mathrm{mg} \mathrm{L}^{-1}$ Thidiazuran (TDZ) + $0.1 \mathrm{mg} \mathrm{L}^{-1}$ Zeatin (ZEA) (\%88.9) ve $1 \mathrm{mg} \mathrm{L}^{-1} \mathrm{TDZ}$ (\%85.7) uygulamalarından elde edilmiştir. En düşük bitki rejenerasyon yüzdesi (\%16.7) ise yaprak eksplantları kullanılan kontrol uygulamasından elde edilmiştir.




\section{INTRODUCTION}

Plants have been used in the treatment in folk medicines since the earliest times of human history (Cragg et al., 1993; Farnsworth, 1993; Eröztürk, 2000). Chemical composition of plants, antimicrobial and other medicinal properties of plants are being investigated in laboratories throughout the world (Nigg and Segler, 1992; Baytop, 1986, Dordevic et al., 2013; Ghasemi Pirbalouti et al., 2013, Rossi et al., 2013; Kalogeropoulos et al., 2014). The extracts and essential oils derived from medicinal plants (Li et al., 2013; Machado et al., 2013; Quassinti et al., 2013) are known to display antibacterial and antifungal effects (Soković et al., 2002) and antimicrobial activities (Olmedo et al., 2014) which are the basis for many applications such as nutrient preservation, pharmacy, alternative medicine and natural therapy. Immortal flower, which is called "Helichrysum pallasii" is a plant of European origin and is widely used for herbal treatment in Turkey (Davis, 1975; Davis, 1988; Lawrence, 1998; Guner et al., 2000; Sumbul et al., 2003; Angioni et al., 2003; Appendino et al., 2007). It is necessary to investigate the methods of rapid plant reproduction that can contribute to both the economy of the country and region. Quality products and drugs are one of the aims in breeding and breeding studies and especially in pharmaceutical and spice plants. Important support should be provided for the collection, characterization and registration of genetic material in the area of field crops in Turkey. Therefore, this study aimed to develop a regeneration protocol for the immortal flower using different explants under tissue culture conditions.

\section{MATERIAL AND METHOD}

\section{Plant Material}

The characterization of collected plant samples was done by Prof. Dr. Serdar Makbul, Faculty of Science, Recep Tayyip Erdogan University in Rize. The seeds of $H$. pallasii were collected from its natural habitat in the Armutlu district of Bayburt province (Turkey) (Figure 1).

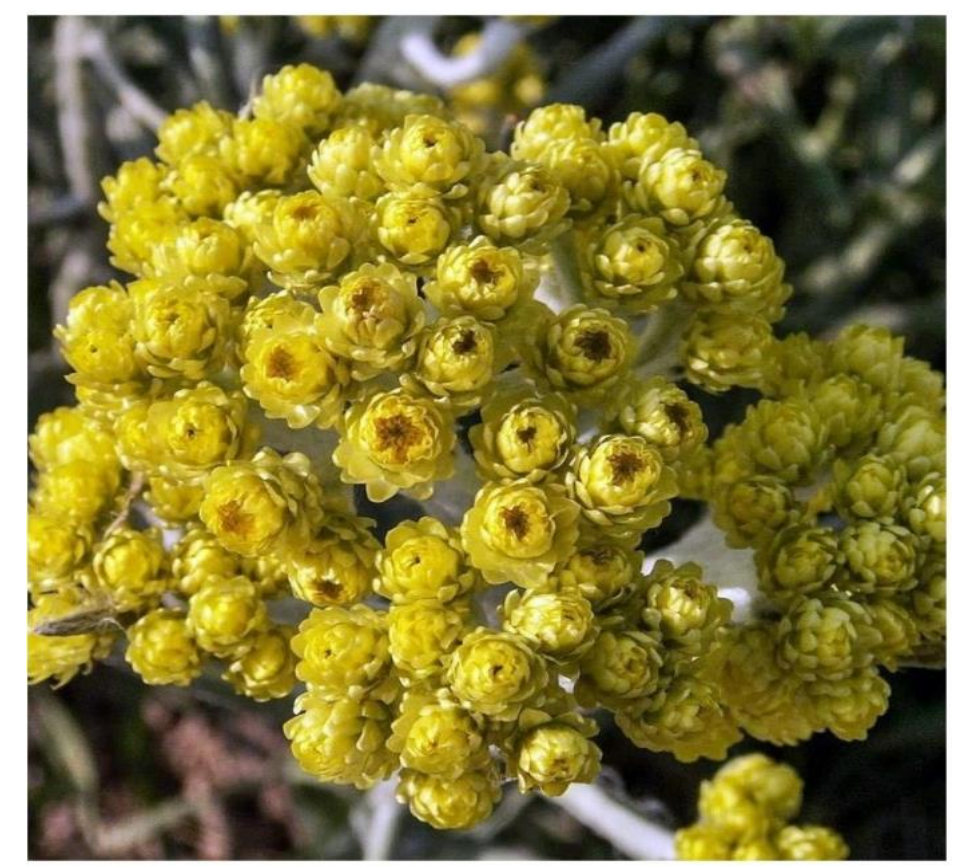

Figure 1. General view of immortal plant (H. pallasii) during the seed filling stage. Şekil 1. Ölmez çiçek (H. pallassii)' nin tohum doldurma döneminde görünümü.

\section{Sterilization and Germination}

Mature seeds of $H$ pallasii were exposed to $70 \%$ ethanol for 5 minutes for pre-sterilization. Thereafter, the seeds were treated with Tween-40 for 10 minutes. Sterilization was carried out with $20 \%$ commercial bleach (Domestos) for 10 minutes. Then, seeds were rinsed in sterile distilled water for $3 \times 5 \mathrm{~min}$. In order to ensure a high percentage of germination, the seeds were planted on MS medium (Murashige and Skoog, 1962), fortified with $30 \mathrm{~g} \mathrm{~L}^{-1}$ sucrose and $7.5 \mathrm{~g} \mathrm{~L}^{-1}$ agar. 


\section{Plant Growth Regulators and Incubation Conditions}

MS medium was used as control treatment. (S1), $1 \mathrm{mg} \mathrm{L}^{-1}$ Thidiazuran (TDZ) (S2) and $1 \mathrm{mg} \mathrm{L}^{-1} \mathrm{TDZ}+0.1$ Zeatin (S3) were used for regeneration purpose. Regenerated shoots were placed into rooting media supplemented with $1 \mathrm{mg} \mathrm{L}^{-1}$ IAA. The explants were cultured under two different incubation conditions of 16 hours light and 8 hours dark conditions at $26^{\circ} \mathrm{C}, 300$ lux light source in growth chamber and dark condition at $26^{\circ} \mathrm{C}$.

\section{Data Analysis}

In order to reduce the dimensional variation problems in multivariate analysis is the first step is the transformation of obtained variables into a number of new and uncorrelated variables, which are called principal component (Mebatsion et al., 2012). Calculated each component corresponds to a percentage of the total variance in the present data set an allows to visualize the characteristic supporting to the differentiation of investigated material. PCA analysis was performed to clarify the relationship between investigated data and principal component analysis (PCA) to elucidate their relationships using the statistical software package XLSTAT2020.

\section{RESULTS AND DISCUSSION}

As explained in Material Methods, seeds of $H$. pallasii were surface sterilized and cultured on MS medium (Figure 2). The surface sterilization and regeneration on MS medium containing different concentrations of plant growth regulators on roots, stem and leaf explants was successful (Figure 2).

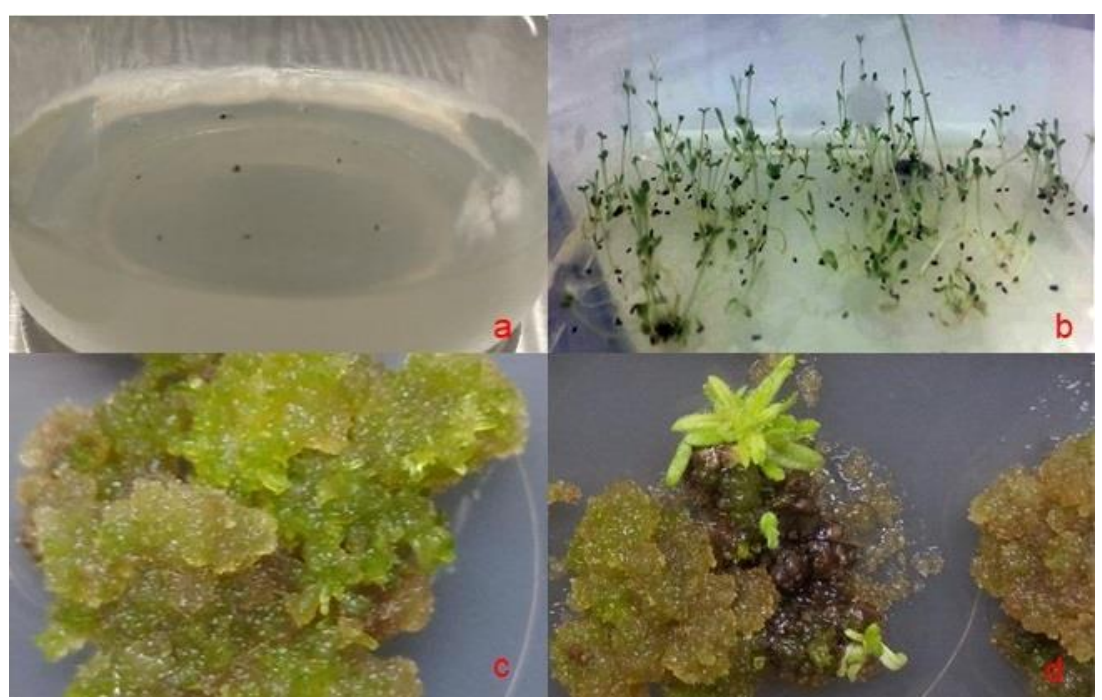

Figure 2. Regeneration of $H$. pallasii under tissue culture conditions; (a) culture of seeds to obtain seedlings, (b) seedlings, (c) callus regeneration and (d) shoot regeneration.

Şekil 2. H. pallasii' nin doku kültürü rejenerasyonu; (a) bitkicik eldesi için tohum kültürü (b) bitkicikler, (c) kallus rejenerasyonu, (d) sürgün rejenerasyonu.

The explants showed variable induction of callus and shoot regeneration (Figure 2a-d)

\section{Callus Regeneration}

The highest callus induction percentage (87.5\%) was noted on the root explants cultured on S3 medium; while the lowest Callus induction (40\%) was determined on S1 medium from the same explant. The highest callus regeneration percentage of $81.3 \%$ on stem explant was noted on S2 medium while the lowest percentage of callusing on the explant was noted on S1 medium (35.7\%). The highest $(51.7 \%)$ and the lowest (24\%) callus regeneration percentage on leaf explants was noted on S3 medium and S1 medium in the same order (Figure 3, Table 1). 


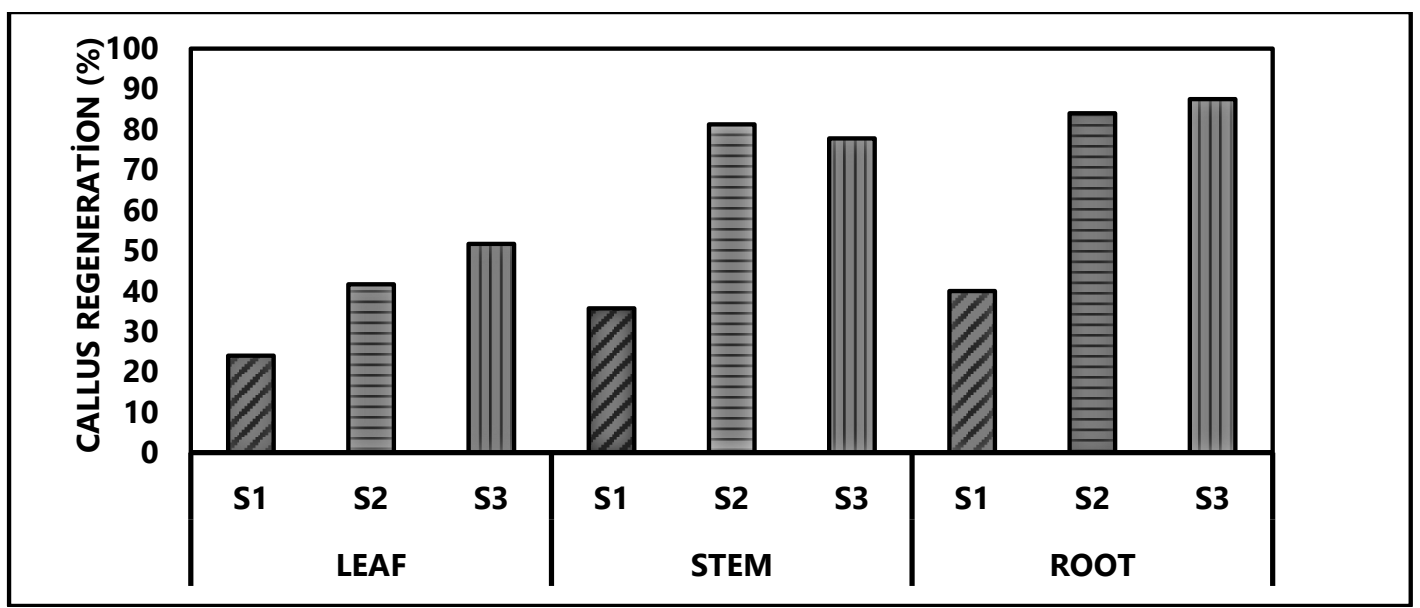

Figure 3. Percentage of regenerated callus obtained from different explant parts using TDZ, TDZ and Zeatin. Şekil 3. TDZ, TDZ and Zeatin kullanılarak farklı eksplant kaynaklarından elde edilen \% kallus rejenerasyonu.

Table 1. Effects of different PGRs treatments on leaf, stem and root explants of $H$. pallasii.

Çizelge 1. Farklı bitki büyüme düzenleyicilerinin H. pallasii de yaprak, gövde ve kök eksplantlarına etkisi.

\begin{tabular}{|c|c|c|c|c|c|c|}
\hline Explant part & Medium & $\begin{array}{l}\text { Number of } \\
\text { explants }\end{array}$ & $\begin{array}{l}\text { Number of } \\
\text { callus }\end{array}$ & $\begin{array}{l}\text { Number of } \\
\text { regenera-ted } \\
\text { plants }\end{array}$ & $\begin{array}{l}\text { Callus } \\
\text { regenera- } \\
\text { tion (\%) }\end{array}$ & $\begin{array}{l}\text { Plant } \\
\text { regenera- } \\
\text { tion (\%) }\end{array}$ \\
\hline \multirow{3}{*}{ Leaf } & S1 & 50 & 12 & 2 & 24.0 & 16.7 \\
\hline & $\mathrm{S} 2$ & 60 & 25 & 15 & 41.7 & 60.0 \\
\hline & S3 & 60 & 31 & 18 & 51.7 & 58.1 \\
\hline \multirow{3}{*}{ Stem } & S1 & 70 & 25 & 11 & 35.7 & 44.0 \\
\hline & S2 & 80 & 65 & 53 & 81.3 & 81.5 \\
\hline & S3 & 90 & 70 & 61 & 77.8 & 87.1 \\
\hline \multirow{3}{*}{ Root } & S1 & 40 & 16 & 8 & 40.0 & 50.0 \\
\hline & S2 & 50 & 42 & 36 & 84.0 & 85.7 \\
\hline & S3 & 40 & 45 & 40 & 87.5 & 88.9 \\
\hline
\end{tabular}

(S1 (Control), S2 (1 $\mathrm{mg} \mathrm{L}^{-1}$ Thidiazuran) and S3 (1 $\mathrm{mg} \mathrm{L}^{-1}$ Thidiazuran $+0.1 \mathrm{mg} \mathrm{L}^{-1}$ Zeatin).

These results are in agreement with Perrini et al. (2009), reporting that TDZ concentrations ( $0.1 \mathrm{Mg} \mathrm{L}^{-1}$ to $\left.2 \mathrm{Mg} \mathrm{L}^{-1}\right)$ were effective in callus regeneration in $H$ italicum.

\section{Plant Regeneration}

Plant regeneration percentages were highest in root explants. In root explants the highest plant regeneration percentage was determined as $88.9 \%$ in S3 medium (Figure 4, Table 1).

The highest percentage of plant regeneration was found on S3 medium as $87.1 \%$, when using stem explants. The lowest plant regeneration (16.7\%) was observed on S1 medium using leaf explants. The highest rate of plant regeneration (60.0\%) using leaf explants was observed on S2 medium (Figure 4, Table 1). All regenerated plants were obtained from callus.

Plant regeneration was encouraged by using $0.1 \mathrm{mg} \mathrm{L}^{-1}$ zeatin combined with $1 \mathrm{Mg} \mathrm{L}^{-1} \mathrm{TDZ}$ (S3) Giovannini et al. (2003) reported that using 0.91 and $4.56 \mu \mathrm{M}$ zeatin singly was not effective to stimulate organogenesis. They reported that a combination of zeatin with IAA $(1$ and $0.5 \mu \mathrm{M})$ encouraged shoot proliferation in $\mathrm{H}$. italicum.

There are no studies regarding the germination and regeneration of plants under in vitro conditions from $H$. pallasii. It is well established that the contamination risk among explants obtained from field conditions is very high compared to the explants taken from plantlets grown under greenhouse or in vitro conditions. The results of the study show that the seeds of $H$. pallasii are not difficult to germinate. A large number of seeds could be multiplied in short time. 


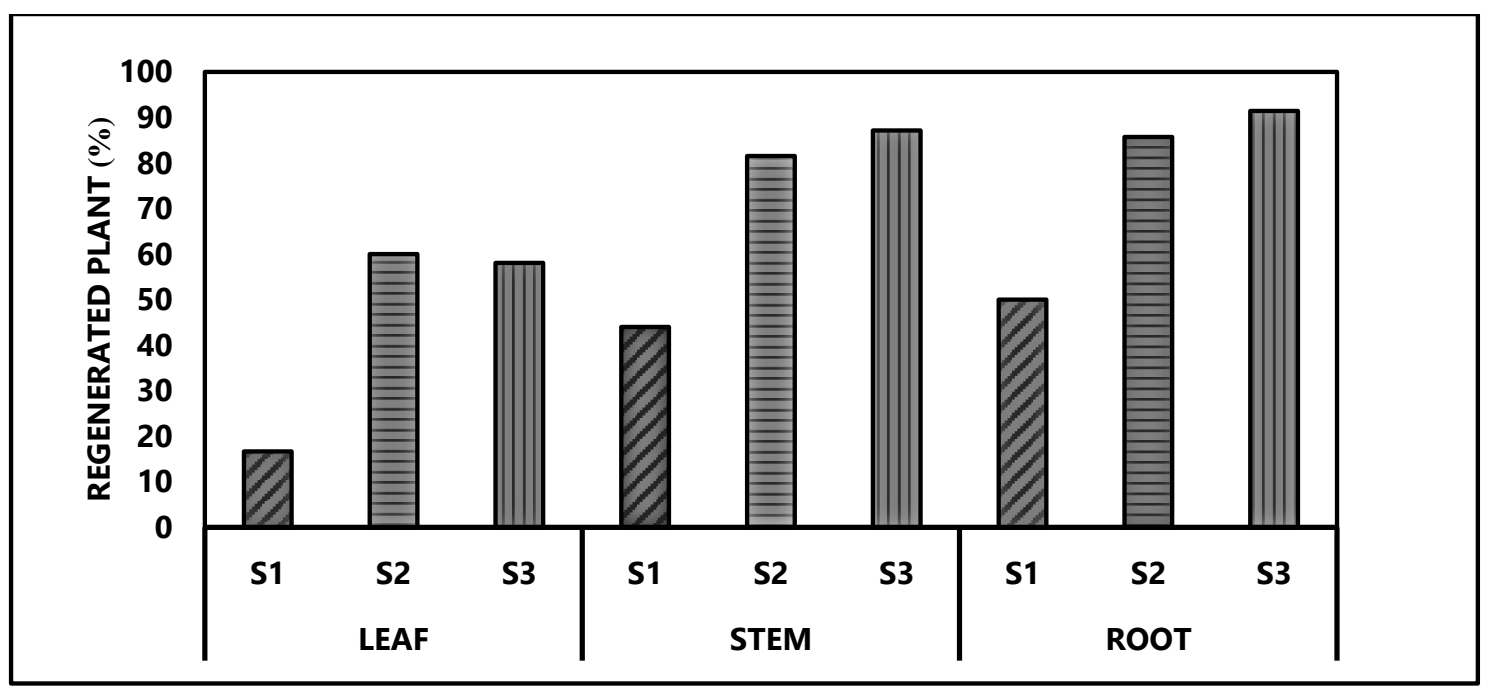

Figure 4. Percentage of regenerated plants taken from different explant parts with TDZ, TDZ and Zeatin. Şekil 4. TDZ ve TDZ + Zeatin uygulanan farklı eksplantlardan elde edilen \% bitki rejenarasyonu.

As can be also seen in Figure 5, PCA of obtained results from the present study revealed that the root explants cultured on S2 and S3 medium were more effective regarding callus regeneration and plant regeneration and stem explants cultured on S2 and S3 medium were effective in obtaining number of regenerated plants and calli.

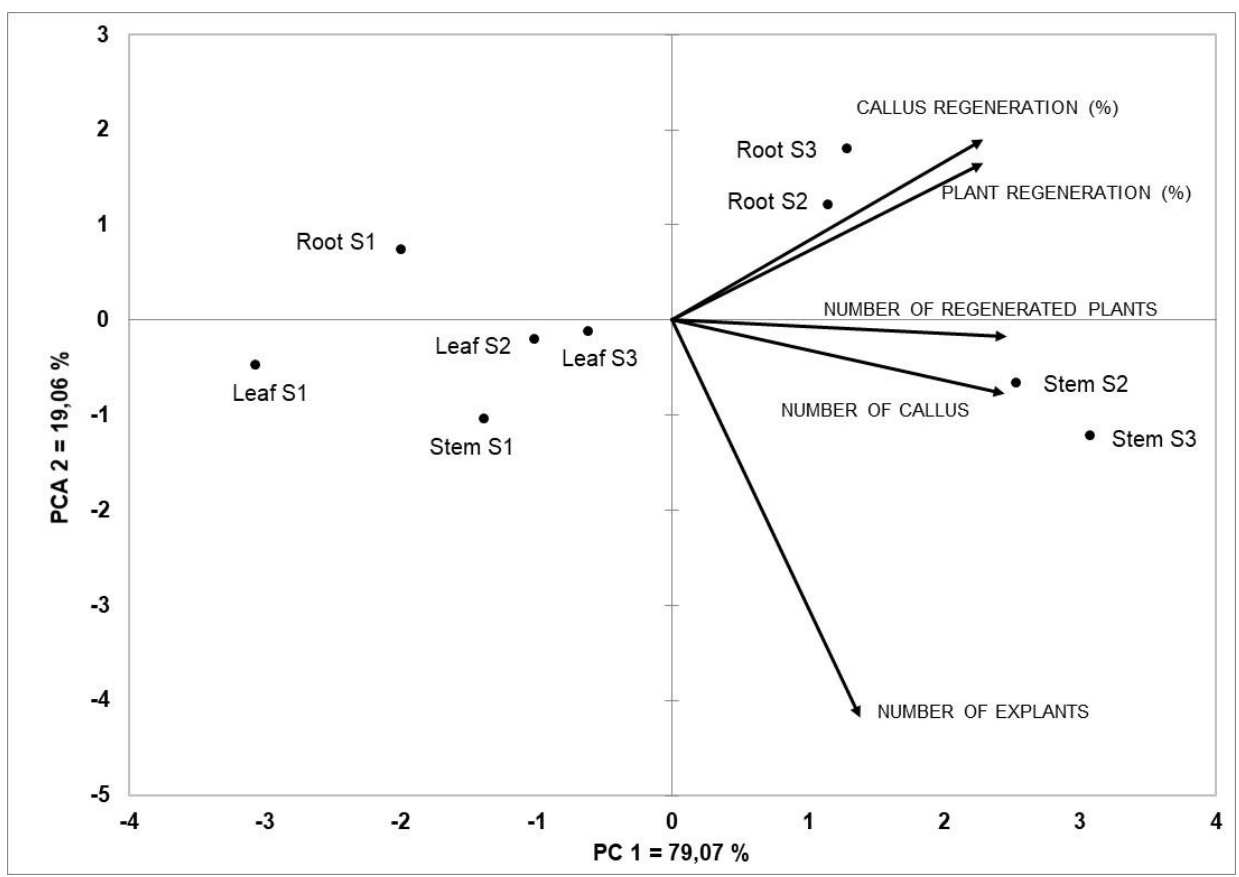

Figure 5. PCA of callus and shoot regeneration of $H$. pallasii tissue culture media containing TDZ, TDZ and Zeatin.

Şekil 5. TDZ ve TDZ + Zeatin içeren besi ortamında yetiştirilen H. pallasii bitkisinde kallus ve sürgün rejenarasyonunun Temel Bileşen Analizi.

\section{CONCLUSION}

Based on obtained results, it can be said that the highest percentage of regenerated plants was obtained using stem and root explants on S3 medium and using leaf explants on S2 medium. This study, tested the regeneration ability of immortal flower using three different explants successfully that will contribute to the breeding and secondary metabolites studies in future and the current study will be beneficial in terms of reducing the duration of breeding time.

\section{ACKNOWLEDGEMENT}

This study was supported by a TUBITAK-2209A project. 


\section{REFERENCES}

Angioni, A., Barra, A., Arlorio, M., Coisson, J. D., Russo, M. T., Pirisi, F. M., Satta, M., \& Cabras, P. (2003). Chemical composition, plant genetic differences, and Antifungal activity of the essential oil of Helichrysum italicum G. Don ssp. microphyllum (Willd) nym. Journal of Agricultural and Food Chemistry, 51(4), 1030-1034.

Appendino, G., Ottino, M., Marquez, N., Bianchi, F., Giana, A., Ballero, M., Sterner, O., Fiebich, B. L., \& Munoz, E. (2007). Arzanol, an anti-inflammatory and Anti-HIV-1 Phloroglucinol $\alpha$-pyrone from Helichrysum italicum ssp. microphyllum. Journal of Natural Products, 70(4), 608-612.

Baytop, T. (1986). Farmakognozi Ders Kitabı. Cilt I. İstanbul Üniversitesi Yayınları, No:3399, İstanbul.

Cragg, G. M., Body, M. R., Cardell, N., Grever, J., Schepartz, M., \& Spader, K. (1993). The Role of Plants in the Drug Discovery Program of the US Manupilation. International Crop Science 1 Maddison, USA: Crop Science Society of America.

Davis, P. H. (1975). Flora of Turkey and the East Aegean Islands. Edinburgh, UK: Edinburgh University Press.

Davis, P. H., Mill, R. R., \& Tan, K. (1988). Flora of Turkey and the East Aegean Islands. Edinburgh, UK: Edinburgh University Press.

Đorđević, A., Lazarević, J., Šmelcerović, A., \& Stojanović, G. (2013). The case of Hypericum rochelii Griseb. and Schenk and Hypericum umbellatum A. Kern. essential oils: Chemical composition and antimicrobial activity. Journal of Pharmaceutical and Biomedical Analysis, 77, 145-148.

Eröztürk, N. (2000). Bir Yudum Sağlık. Anahtar Kitap Yayınları, İstanbul.

Farnsworth, N. R. (1993). Ethnopharmacology and future drug development: The North American experience. Journal of Ethnopharmacology, 38(2-3), 137-143.

Ghasemi Pirbalouti, A., Hashemi, M., \& Ghahfarokhi, F. T. (2013). Essential oil and chemical compositions of wild and cultivated Thymus daenensis Celak and Thymus vulgaris L. Industrial Crops and Products, 48, 43-48.

Giovannini, A., Amoretti, M., Savona, M., Di Guardo, A., \& Ruffoni, B. (2003). Tissue Culture in Helichrysum spp. Acta Horticulturae, 616, 339-342.

Guner, A., Ozhatay, N., Ekim, T., \& Baser, K. H. C. (2000). Flora of Turkey and the East Aegean Islands. Edinburgh, UK: Edinburgh University Press.

Kalogeropoulos, N., Kaliora, A. C., Artemiou, A., \& Giogios, I. (2014). Composition, volatile profiles and functional properties of virgin olive oils produced by two-phase vs three-phase centrifugal decanters. Food Science and Technology, 58(1), 272279.

Lawrence, B. M. (1998). Helichrysum oil and extract. Perfumer Flavorist, 23(5), 55-59.

Li, Y., Kong, D., \& Wu, H. (2013). Analysis and evaluation of essential oil components of Cinnamon barks using GC-MS and FTIR spectroscopy. Industrial Crops and Products, 41, 269-278

Machado, D. G., Cunha, M. P., Neis, V. B., Balen, G. O., Colla, A., Bettio, L. E., Oliveira, Á., Pazini, F. L., Dalmarco, J. B., Simionatto, E. L., Pizzolatti, M. G., \& Rodrigues, A. L. (2013). Antidepressant-like effects of fractions, essential oil, carnosol and betulinic acid isolated from Rosmarinus officinalis L. Food Chemistry, 136(2), 999-1005.

Mebatsion, H., Paliwal, J., \& Jayas, D. (2012). Evaluation of variations in the shape of grain types using principal components analysis of the elliptic fourier descriptors. Computers and Electronics in Agriculture, 80, 63-70.

Murashige, T., \& Skoog „F. (1962). A revised medium for rapid growth and bio assays with tobacco tissue cultures. Physiologia Plantarum, 15(3), 473-497.

Nigg, H. N., \& Seigler, D. (1992). Phytochemical Resources for Medicine and Agriculture. Springer, USA.

Olmedo, R., Nepote, V., \& Grosso, N. R. (2014). Antioxidant activity of fractions from oregano essential oils obtained by molecular distillation. Food Chemistry, 156, 212-219.

Perrini, R., Ruta, C., \& Morone Fortunato, I. (2009). Regeneration through organogenesis from leaves of Helichrysum italicum (Roth) G. Don. Acta Horticulturae, 812, 217-222.

Quassinti, L., Bramucci, M., Lupidi, G., Barboni, L., Ricciutelli, M., Sagratini, G., Papa, F., Caprioli, G., Petrelli, D., Vitali, L. A., Vittori, S., \& Maggi, F. (2013). In vitro biological activity of essential oils and isolated furanosesquiterpenes from the neglected vegetable Smyrnium olusatrum L. (Apiaceae). Food Chemistry, 138(2-3), 808-813.

Rossi, D., Guerrini, A., Paganetto, G., Bernacchia, G., Conforti, F., Statti, G., Maietti, S., Poppi, I., Tacchini, M., \& Sacchetti, G. (2013). Croton lechleri Müll. Arg. (Euphorbiaceae) stem bark essential oil as possible mutagen-protective food ingredient against heterocyclic amines from cooked food. Food Chemistry, 139(1-4), 439-447. 
Soković, M., Tzakou, O., Pitarokili, D., \& Couladis, M. (2002). Antifungal activities of selected aromatic plants growing wild in Greece. Die Nahrung, 46(5), 317-320.

Sumbul, H., Gokturk, R. S., \& Dusen, O. D. (2003). A new endemic species of Helichrysum Gaertn. (Asteraceae-Inuleae) from south Anatolia. Botanical Journal of the Linnean Society, 141, 251-254. 